\title{
Different presentations of cow's milk protein allergy during neonatal period
}

\author{
Selma Aktaş ${ }^{1}$ Ebru Ergenekon², Sezin Ünal ${ }^{3}$, Canan Türkyılmaz², İbrahim Murat Hirfanoğlu², \\ Yildız Atalay ${ }^{2}$ \\ ${ }^{1}$ Division of Neonatology, Department of Pediatrics, Gaziosmanpasa Taksim Research and Training Hospital, İstanbul, \\ Division of Neonatology, ${ }^{2}$ Department of Pediatrics, Gazi University Faculty of Medicine, ${ }^{3}$ Etlik Zubeyde Hanim Research \\ and Training Hospital, Ankara, Turkey. E-mail:selmaktas@gmail.com \\ Received: 21st November 2016, Revised: 3rd January 2017, Accepted: 4th January 2017
}

SUMMARY: Aktaş S, Ergenekon E, Ünal S, Türkyılmaz C, Hirfanoğlu İM, Atalay Y. Different presentations of Cow's milk protein allergy during neonatal period. Turk J Pediatr 2017; 59: 322-328.

Cow's milk protein allergy (CMPA) is the most common cause of allergy occurring in the first year of life due to infant formula or breast-milk of mothers who are drinking cow's milk or eating cow's milk products. Most children with allergic colitis are symptomatic in the first months, usually by 4 weeks. There are rare cases whom were sensitized prenatally and demonstrated symptoms in the first week, even in the first 2 days of life. The most common clinical sign of CMPA is bloody stool in a well-appearing infant. Gross bloody stool or fecal occult blood are also the common signs of necrotizing enterocolitis (NEC), especially in preterm infants with systemic instability. The treatment options are totally different so the clinician has to be very careful evaluating the patient. We report 5 preterm cases of CMPA, two of whom were siblings. Two of them presented with massive bloody stools and 3 of them presented with abdominal distension and fecal occult blood all of which were initially considered as NEC. Literature review of 20 cases with similar history is summarized as well.

Key words: cow's milk protein allergy, neonate, prematurity, differential diagnosis.

Cow's milk protein allergy (CMPA) is the most common cause of allergy in infants ${ }^{1}$. The incidence of CMPA in the first year of life is $2-7 \%$ and is reported as $0.34-2 \%$ in preterms $^{2}$, although there seems to be an increase in recent years in preterm population. Since 1990, 20 cases who were diagnosed to have CMPA during neonatal period have been reported in English literature ${ }^{1-14}$. The most common clinical sign of CMPA is bloody stool in a well-appearing infant. However in a preterm infant with rectal bleeding, necrotizing enterocolitis (NEC) is considered at top of the list of possible conditions. There are case reports of food protein induced proctocolitis secondary to CMPA presenting as recurrent NEC in preterm neonates ${ }^{3}$. Although NEC is a life-threatening event for infants, CMPA is relatively benign and self limited. Extraintestinal signs of CMPA are rare among neonates making the diagnosis more difficult ${ }^{2}$.
Usually the infants tolerate a normal diet by the end of first year ${ }^{4}$. We report 5 preterm cases of CMPA, two of whom were siblings. Two of them presented with massive bloody stools and 3 of them presented with abdominal distension and fecal occult blood all of which were initially considered as NEC (Table I). We also provide a summary of 20 cases reported in the English literature (Table II).

\section{Case 1}

A female preterm baby was born to a 20 -year-old mother at 32 weeks gestation by vaginal delivery with birth weight of 1950 g. Prophylactic antibiotic (ampicillin and amikacin) was began because of preterm delivery after sending blood culture. Trophic feeds were started on the second day of life with breast milk. Feedings were advanced at 20-30 $\mathrm{ml} / \mathrm{kg} /$ day and the baby was on full enteral feeds on fifth day of life with breast milk and 
preterm formula. The blood culture was sterile so the antibiotics were stopped. During follow up, diaper rash occurred on the perianal region which was resistant to therapy. On the 12th day of life the baby was clinically well but developed grossly bloody stools with minimal abdominal distension. The plain abdominal X-ray revealed no signs of NEC. Laboratory testing showed $\mathrm{Hb}$ of $13.3 \mathrm{~g} / \mathrm{dl}$, white blood cell count $21 \times 10^{3} / \mu \mathrm{L}$ with $0,7 \%$ eosinophils and normal platelet count, C-reactive protein (CRP) was $10.5 \mathrm{mg} / \mathrm{L}$. Since the baby was clinically well we suspected cow's milk-induced proctocolitis and continued feeding with amino acid-based formula. During the following 3 days grossly bloody stools continued but her clinical condition remained well and abdominal radiographs did not indicate NEC. At 4th day of neocate bloody stools disappeared however fecal occult blood was positive which disappeared on the 6th day of aminoacid-based formula. Blood culture which was sampled when the symptoms began remained sterile. After feeding with aminoacid-based formula perianal rash also disappeared. The baby was discharged on aminoacid-based formula.

\section{Case 2}

A male late preterm baby was born to a 33-yearold mother at 36 weeks gestation by cesarean section with a birth weight of $2500 \mathrm{~g}$. The baby was evaluated for pallor after delivery. The $\mathrm{Hb}$ level was $8.99 \mathrm{~g} / \mathrm{dl}$, white blood cell count was $16,7 \times 10^{3} / \mu \mathrm{L}$, platelet count was $193 \times 10^{3} / \mu \mathrm{l}$ and CRP was $11.5 \mathrm{mg} / \mathrm{L}$, so the baby was admitted to the NICU for anemia and possible early neonatal sepsis. After sending blood culture,

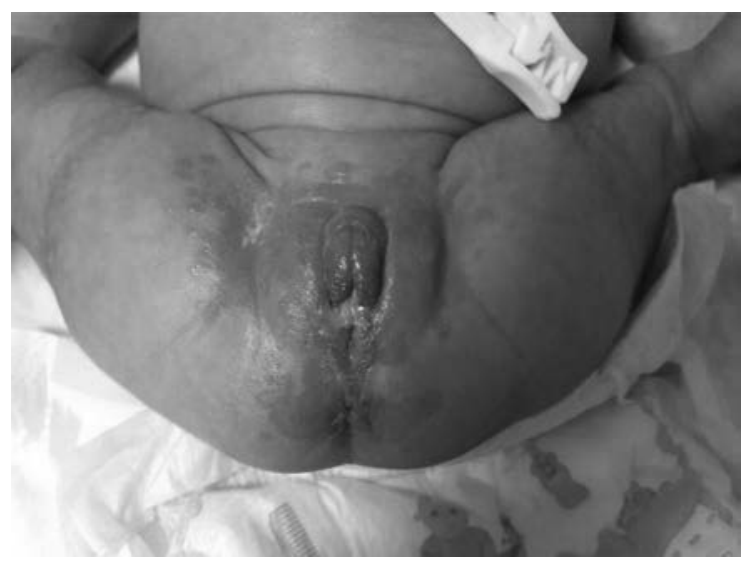

Fig. 1a. Perianal excoriated lesion due to cow's milk protein allergy before elimination diet. ampicillin and amikacin therapy was began. He was investigated for anemia. The blood type of the mother was $\mathrm{O} R \mathrm{Rh}$ positive and the infant was B Rh positive, direct Coombs test was negative. Reticulocyte count was $2 \%$. Peripheral smear of blood revealed no sign of hemolysis. The infant was symptomatic so he was transfused. Before transfusion toxoplasma, rubella, CMV and parvovirus IgM and $G$ were sent. All IgM results were negative. Transfontanelle and abdominal ultrasonography were all normal and revealed no hemorrhage. So fetomaternal hemorrage was accepted as the cause of anemia. After transfusion the $\mathrm{Hb}$ level was $13 \mathrm{~g} / \mathrm{dl}$. On the 4th day of life grossly bloody stools was noticed. The clinical condition of the infant remained well and plain radiographs of abdomen were normal. The infant was on full enteral feeds with breast milk. Laboratory testing showed $\mathrm{Hb} 13$ $\mathrm{g} / \mathrm{dl}$, white blood cell count $11.8 \times 10^{3} / \mu \mathrm{L}$, with $22.5 \%$ eosinophils and normal platelet count. CRP became positive during follow up. We thought cow's milk-induced proctocolitis due to good clinical condition and eosinophilia. Feeding was continued with aminoacid-based formula. Gross bloody stools continued for 8 days and occult blood in stools continued for another 3 days. The blood culture was sterile. The baby was discharged on amino acid-based formula .

\section{Case 3}

A female preterm infant was born to a 21-yearold mother at 31 weeks gestation by cesarean section with birth weight $1300 \mathrm{~g}$ after triplet pregnancy. The infant was intubated in the delivery room and admitted to the NICU. The mother had epilepsy and had to use valproic acid. The infant was treated with surfactant

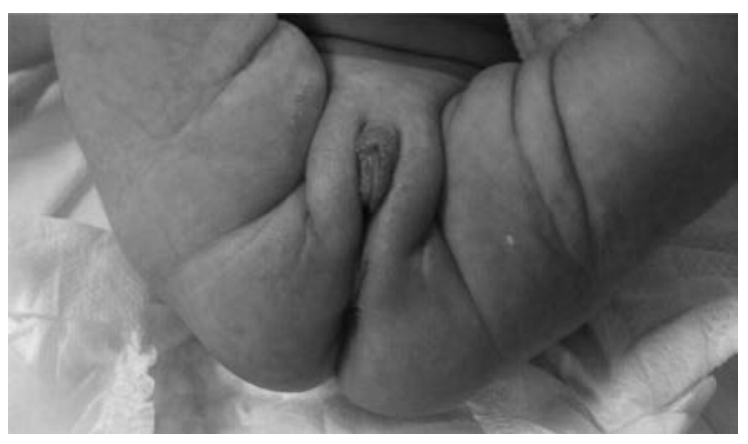

Fig. 1b. Perianal excoriated lesion disappeared totally after elimination diet. 
Table I. The Summary of the Findings of 5 Cases Presented.

\begin{tabular}{|c|c|c|c|c|c|c|}
\hline & $\mathrm{Hb}(\mathrm{g} / \mathrm{dl})$ & WBC $\left(/ \mathrm{mm}^{3}\right) \mu \mathrm{l}$ & EOS (\%) & CRP (mg/L) & GBS & FOB \\
\hline Case 1 & $\begin{array}{l}\text { DOL } 12-13.3 \\
\text { DOL } 13-12 \\
\text { DOL } 16-9.9 \\
\text { DOL } 18\end{array}$ & $\begin{array}{l}21000 \\
14800 \\
16500\end{array}$ & $\begin{array}{l}0.7 \\
0.5 \\
0.7\end{array}$ & $\begin{array}{l}10.5 \\
4.64 \\
3.2\end{array}$ & $\begin{array}{l}+ \\
+ \\
-\end{array}$ & $\begin{array}{l}+ \\
+ \\
+ \\
-\end{array}$ \\
\hline Case 2 & $\begin{array}{l}\text { DOL } 4-13.2 \\
\text { DOL } 6-11.5 \\
\text { DOL } 9-9.3 \\
\text { DOL } 15-9.2\end{array}$ & $\begin{array}{l}11800 \\
13700 \\
16600 \\
13300\end{array}$ & $\begin{array}{l}22.5 \\
26.4 \\
11.5 \\
6\end{array}$ & $\begin{array}{l}3.1 \\
3.1 \\
15.1 \\
3.1\end{array}$ & $\begin{array}{l}+ \\
+ \\
+ \\
-\end{array}$ & $\begin{array}{l}+ \\
+ \\
+ \\
-\end{array}$ \\
\hline Case 3 & $\begin{array}{l}\text { DOL16-10.85 } \\
\text { DOL22-8.3 } \\
\text { DOL24-11 } \\
\text { DOL38-7.65 }\end{array}$ & $\begin{array}{l}13000 \\
7660 \\
7600 \\
7160\end{array}$ & $\begin{array}{l}5.27 \\
12.38 \\
9.5 \\
2.61\end{array}$ & $\begin{array}{l}4.46 \\
1.5 \\
1 \\
1\end{array}$ & & $\begin{array}{l}+ \\
+ \\
- \\
-\end{array}$ \\
\hline Case 4 & $\begin{array}{l}\text { DOL } 18-8 \\
\text { DOL } 20-12^{\sharp} \\
\text { DOL } 23-11.1 \\
\text { DOL } 30-10\end{array}$ & $\begin{array}{l}9000 \\
11890 \\
8880 \\
11650\end{array}$ & $\begin{array}{l}2.8 \\
1.65 \\
6.5 \\
1.5\end{array}$ & $\begin{array}{l}1 \\
1 \\
1 \\
1\end{array}$ & & $\begin{array}{l}- \\
+ \\
+ \\
-\end{array}$ \\
\hline Case 5 & $\begin{array}{ll}\text { DOL } & 14-12.6 \\
\text { DOL } & 15-10.2 \\
\text { DOL } & 18-10.6 \\
\text { DOL } 24-7.04\end{array}$ & $\begin{array}{l}17900 \\
16300 \\
20350 \\
13200\end{array}$ & $\begin{array}{l}6 \\
8.3 \\
20 \\
4\end{array}$ & $\begin{array}{l}1 \\
1.5 \\
12 \\
2.5\end{array}$ & & $\begin{array}{l}+ \\
+ \\
- \\
-\end{array}$ \\
\hline
\end{tabular}

$¥ \mathrm{Hb}$ level after RBC transfusion, CRP (C-reactive protein), DOL (day of life), EOS (dosinophil), FOB (fecal occult blood), GBS (gross bloody stool), Hb (haemoglobin), WBC (white blood cell count)

due to respiratory distress syndrome. Ampicillin and amikacin therapy was started for preterm delivery and stopped on the 10th day of life. The infant was extubated on the second day of life and followed on nasal intermittant mandatory ventilation. On the 3rd day of life intravenous ibuprofen was given for patent ductus arteriosus. On the same day trophic feeding was also started with breast milk. Feedings were advanced $10-20 \mathrm{ml} / \mathrm{kg} /$ day. On the 16th day of life while the baby was feeding with $7 \mathrm{ml}$ breast milk every 2 hours, abdominal distension was observed. NEC and sepsis was suspected, so plain radiography of abdomen, blood culture, CRP and blood count were evaluated. Plain radiograph of abdomen revealed dilated loops only, CRP was negative and white blood cell count and platelet count were normal. Fecal occult blood was positive. Feeding was stopped and vancomycin and meropenem therapy were started. On the 4th day of antibiotherapy plain radiography of abdomen was normal, feeding was restarted with breastmilk. Clinical condition of the infant remained well but fecal occult blood was positive again and eosinophilia (10\%) was present. Breast milk was stopped and amino acid-based formula was started for suspicion of cow's milk-induced proctocolitis. Then the fecal occult blood became negative and eosinophilia disappeared. The blood culture which was sampled during the symptoms was sterile and after neocate the symptoms did not reoccur. The baby was discharged with amino acid based formula 1 month after delivery.

\section{Case 4}

A female preterm infant was born to a 21year-old mother at 31 weeks gestation by c/s with birth weight of $1215 \mathrm{~g}$ following triplet pregnancy. The baby was admitted to the NICU on NCPAP and followed on NCPAP for 1 day. Ampicillin and amikacin therapy was began for preterm delivery and stopped on the 5th day of life. The mother had epilepsy and had to use valproic acid. On the 3rd day of life trophic feeding was began with breastmilk and she was on full enteral feeds on the 15th day of life with exclusive breast milk. On the second day of full enteral feeds, human milk fortifier was added to the breast milk. On the 20th day of life abdominal distension developed and fecal occult blood was positive. NEC was suspected, so feeding was stopped, blood culture, blood cell count and CRP tests were sent. CRP was negative and the blood culture was sterile. 
Plain radiograph of abdomen revealed dilated loops only. Vancomycin and meropenem was started due to suspicion of NEC. During follow up eosinophil count increased from $1.85 \%$ to $6.5 \%$. Sister of the infant was diagnosed with cow's milk induced proctocolitis (Case 3) and after feeding with amino acid-based formula the symptoms had disappeared. Therefore considering sibling's history, eosinophilia and negative blood culture; we began to feed baby with aminoacid-based formula. On the 4th day of aminoacid-based formula, fecal occult blood

Table II. Findings and Treatment of Cases in English Literature With CMPA.

\begin{tabular}{|c|c|c|c|c|c|c|}
\hline Case & GA & $\begin{array}{l}\text { Day of } \\
\text { presentation }\end{array}$ & Symptom & Abd X-ray & Laboratory & Treatment \\
\hline $1^{8}$ & 37 & 1 & Bloody stool & Normal & Eosinophilia & Neocate \\
\hline $2^{4}$ & 31 & 28 & $\begin{array}{l}\text { Bloody } \\
\text { stool+abd } \\
\text { dist+anemia }\end{array}$ & Normal & $\begin{array}{l}\text { High Eos }+ \text { in } \\
\text { stool }\end{array}$ & Nutramigen \\
\hline $3^{4}$ & 31 & $>28$ days & $\begin{array}{l}\text { Bloody stools } \\
+ \text { abd dist }\end{array}$ & Normal & $\begin{array}{l}\text { High eos }+ \text { in } \\
\text { stool }\end{array}$ & Nutramigen \\
\hline $4^{6}$ & 39 & 6 & Bilious vomiting & Malrotation & $\begin{array}{l}\text { Increased } \\
\text { lymphocyte } \\
\text { response to casein }\end{array}$ & Breast milk \\
\hline $5^{1}$ & 31 & 10,30 & Bloody stools & Normal & $\begin{array}{l}\text { Eos, RAST + at } \\
35 \text { days }\end{array}$ & Neocate \\
\hline $6^{1}$ & 31 & 10,27 & Bloody stools & $\begin{array}{l}\text { Dilated loops, } \\
\text { pneumatosis }\end{array}$ & Eos, RAST + & $\begin{array}{l}\text { Neocate } \\
\text { and NEC } \\
\text { treatment X2 }\end{array}$ \\
\hline $7^{3}$ & 26 & $17,28,61$ & $\begin{array}{l}\text { Abd dist, bloody } \\
\text { stools }\end{array}$ & Pneumatosis & Eos & $\begin{array}{l}\text { Neocate,NEC } \\
\text { treatment X2 }\end{array}$ \\
\hline $8^{7}$ & 28 & 14,30 & $\begin{array}{l}\text { Abd dist, bloody } \\
\text { stools }\end{array}$ & Normal & Eos & $\begin{array}{l}\text { Nutramigen, } \\
\text { NEC }\end{array}$ \\
\hline $9^{7}$ & 27 & 41 & Bloody stools & Normal & Eos & $\begin{array}{l}\text { treatment x1 } \\
\text { Neocate }\end{array}$ \\
\hline $10^{7}$ & 25 & 20 & Abd dist & Normal & Eos & Neocate \\
\hline $11^{9}$ & 38 & 10 & $\begin{array}{l}\text { Bilious vomiting, } \\
\text { bloody stools }\end{array}$ & Normal & Eos, + prick test & $\begin{array}{l}\text { Casein } \\
\text { hydrolized } \\
\text { formula }\end{array}$ \\
\hline $12^{10}$ & 39 & 15 & Abd dist & Normal & - & Neocate \\
\hline $13^{5}$ & term & 7 & $\begin{array}{l}\text { Bilious vomiting, } \\
\text { bloody stools }\end{array}$ & Normal & Eos & $\begin{array}{l}\text { Cows milk } \\
\text { eliminated }\end{array}$ \\
\hline $14^{5}$ & term & 5 & $\begin{array}{l}\text { Bilious vomiting, } \\
\text { bloody stools }\end{array}$ & Normal & Eos, biopsy eos inf & Elimination \\
\hline $15^{11}$ & preterm & 1 & Bloody stools & Normal & $\begin{array}{l}\text { Cows milk allergy } \\
\text { test }+\end{array}$ & Elimination \\
\hline $16^{12}$ & term & 15 & Reflux & Normal & & Elimination \\
\hline $17^{13}$ & term & 2 & Bloody stools & Normal & $\begin{array}{l}\text { Biopsy eos inf } \\
\text { edema }\end{array}$ & $\begin{array}{l}\text { Elimination } \\
\text { antibiotics }\end{array}$ \\
\hline $18^{13}$ & term & 2 & Bloody stools & Normal & biopsy & $\begin{array}{l}\text { Antibiotics } \\
\text { elimination }\end{array}$ \\
\hline $19^{13}$ & term & 2 & Bloody stools & Normal & biopsy & Elimination \\
\hline $20^{14}$ & term & 4 & Rectal bleeding & Normal & $\begin{array}{l}\text { RAST }+ \text {,prick test } \\
+\end{array}$ & Nutramigen \\
\hline
\end{tabular}


was negative, the antibiotics were stopped. The infant was discharged with aminoacid-based formula on the 54th day of life.

\section{Case 5}

A male preterm infant was born to 24 year-old, preeclamptic mother at 34 weeks gestation by $\mathrm{c} / \mathrm{s}$ with birth weight of $1495 \mathrm{~g}$. The mother had used alpha methyldopa $(3 \times 250 \mathrm{mg})$ for six weeks due to preeclampsia. The infant was on NCPAP for 1 day because of tachypnea. Trophic feeding was began on the second day and the infant was on full enteral feeds on the 6 th day of life with breast milk. On the 14th day of life while feeding with $35 \mathrm{ml}$ breast milk every 3 hours and fortified with eoprotin (Milupa, Friedrichsdorf, Germany) abdominal distension developed. Plain radiography of abdomen revealed dilated loops. Fecal occult blood was positive, CRP was negative at the beginning and became positive 2 days later, blood culture and stool culture were negative. Blood examination showed no signs of infection and only revealed eosinophilia (20\%). CMPA was suspected, aminoacid-based formula was started. On the 3rd day of aminoacid-based formula fecal occult blood became negative. During follow up eosinophilia disappeared. The infant was discharged 1 month later with aminoacid-based formula. All findings of 5 cases are summarized in Table I.

The 20 cases of neonatal CMPA we identified in English literature are summarized in Table II. The findings of presentation, abdominal X-rays are quite similar to the 5 cases presented above. Six of the cases were diagnosed by allergy tests, 4 of them had intestinal biopsy findings suggestive of inflammation, the remaining 9 cases were diagnosed based on clinical findings and response to cow's milk protein free feeding regimen.

Informed consents were received from the family of all patients.

\section{Discussion}

The prevelance of food allergy has increased in recent decades and CMPA is the most common form in infants ${ }^{15}$. CMPA is considered to develop due to exposure to cow's milk proteins transferred via breast milk and/or formula ${ }^{1}$. Approximately half of the cases occur during exclusive breastfeeding supporting the possibility of transfer of cow's milk protein via breast milk ${ }^{2}$. The most common clinical type in the neonatal period is food protein induced proctocolitis which causes chronic blood loss and anemia by either occult or gross bleeding in the stools. Although massive bloody stools is an uncommon clinical manifestation, some cases can show moderate to massive rectal bleeding shortly after birth ${ }^{5}$. Most of the infants are symptomatic between 2 and 6 weeks of age and are predominantly term infants ${ }^{15}$. However, some rare cases who developed CMPA as early as at the first week of life have been reported ${ }^{11,13}$. In these term and preterm newborns who presented with early rectal bleeding and with no other systemic, abdominal and radiological findings of NEC, the early onset may be secondary to intrauterine sensitization ${ }^{3}$. Two of our cases had presented with massive bloody stool and developed anemia, while the others had fecal occult blood. Four of them developed symptoms between 2 and 3 weeks of age and one of them was symptomatic in the first week oflife( 4 days of age). The infant who was symptomatic on the 4th day of life had massive bloody stools and became anemic, possibly due to intrauterine sensitization. Four of the cases presented here were breast -fed and one of them was fed with combination of breastmilk, fortified breast-milk and/or formula. Infants with CMPA are usually reported to be surprisingly well-appearing despite rectal bleeding with or without mucous stools or diarrhea. However NEC is the most important differential diagnosis to exclude in preterm neonates with rectal bleeding especially if accompanied with signs of systemic instability. As seen in the literature review 3 preterm cases and 1 term newborn had presented with signs of NEC and initially treated as such who later were diagnosed to have allergic proctocolitis $1,3,7$. Two of them even received NEC treatment twice ${ }^{1,3}$. NEC was suspected in three of our preterm cases because of abdominal distension, CRP positivity and dilated intestinal loops on plain radiography which necessitated broad spectrum antibiotics and cessation of enteral feeding at least for a short period of time.

Extra-intestinal signs or other manifestations of allergy are considered unusual in preterm infants ${ }^{16}$, however some excoriated lesions were visible in the perianal region in one of our cases and lesions disappeared after elimination 
of cow's milk from diet (Fig. 1a,1b).

The diagnosis of CMPA in the neonatal period is usually based on clinical response to the elimination of the allergen from the diet and rechallenge ${ }^{5}$, since most laboratory tests including skin prick tests and specific IgE titers are negative in most infants. Laboratory findings of infants with CMPA may include peripheral blood eosinophilia, midly elevated seum IgE, microcytic anemia. These results, although nonspecific may support allergic origin ${ }^{5}$. Eosinophilia can be found in approximately $50 \%$ of patients with CMPA. Eosinophils in stool are considered suggestive of CMPA as well as peripheral eosinophilia ${ }^{17}$. Endoscopic examination is necessary for refractory cases to exclude other causes ${ }^{1}$. In the 20 cases reported in literature $30 \%$ had allergy tests positive and $20 \%$ had undergone intestinal biopsy for diagnosis, the remainder $50 \%$ were diagnosed based on response to elimination diet. Except one case, all of our cases had peripheral eosinophila and all of them responded to the elimination so none of them underwent endoscopic examination.

The elimination of cow's milk protein for formula fed infants is possible either with extensively hydrolyzed protein formula or aminoacid based formula; for breast-fed infants, all foods that contain cow's milk protein are eliminated from the diet of mother and 3 days after elimination mother can breastfeed the infant ${ }^{18}$. Symptoms such as rectal bleeding generally disappear within 72-96 hours after elimination. In our case series aminoacid based formula was used, and except one case rectal bleeding disappeared 72-96 hours after elimination. The oral challenge test which is a method of diagnosis in older children can not be performed in premature infants and in neonatal age because of the risks ${ }^{1}$. All of our patients were premature who were at risk for NEC. So we did not prefer to perform the oral-challenge test for the consequences such as feeding intolerance which would complicate patient care significantly. One of the interesting features of our case series was that there were monozygotic triples and two were diagnosed with CMPA. This may be due to an inherited immune regulation abnormality, leading to poor tolerance ${ }^{4}$. Another possibility is the microbiota which was transferred largely through the gastrointestinal tract and the vagina of the mother to the infants during delivery ${ }^{19}$. It is known that the gastrointestinal microbiota are transferred from mother to the baby and this may explain why the disease develops in siblings, especially twins ${ }^{20}$. Coviello et al. ${ }^{1}$ and Baldassarre et al. ${ }^{4}$ have also reported monozygotic infants who were diagnosed and treated as CMPA as in our case series.

Most of the infants who have CMPA regain tolerance within the five years of life, especially at the end of first year. So every 6 to 12 months re-indroduction needs to be tried to assess whether they have developed tolerance to decide to end elimination $\operatorname{diet}^{8}$. All of our cases were lost to follow up so we are unable to provide information if they became tolerant or not and when.

In conclusion, CMPA is one of the causes of bloody stools in infants even in preterm newborns. The facts that there is no specific diagnostic test of this condition during neonatal period and the high risk of the preterms to develop NEC, generally prompts antibiotic treatment and discontinuation of feedings in a preterm who develops bloody stools. However, CMPA should be kept in mind in this population, especially if the baby's general condition is well and eosinophilia is present with normal abdominal X-rays. Generally diagnosis is based on response to elimination diet and recurrence with reintroduction of cow's milk protein in the diet.

\section{REFERENCES}

1. Coviello C, Rodriquez DC, Cecchi S, et al. Different clinical manifestation of cow's milk allergy in two preterm twins newborns. J Matern Fetal Neonatal Med 2012; 25: 132-133.

2. Swart JF, Ultee K. Rectal bleeding in a preterm infant as a symptom of allergic colitis. Eur J Pediatr 2003; 162: $55-56$

3. Srinivasan P, Brandler M, D'Souza A, Millman P,Moreau $\mathrm{H}$. Allergic enterocolitis presenting as recurrent necrotizing enterocolitis in preterm neonates. J Perinatol 2010; 30: 431-433.

4. Baldassarre ME, Cappiello A, Laforgia N, Vanderhoof J. Allergic colitis in monozygotic preterm twins. Immunopharmacol Immunotoxicol 2013; 35: 198-201.

5. Hirose R, Yamada T, Hayashida Y. Massive bloody stools in two neonates caused by cow's milk allergy. Pediatr Surg Int 2006; 22: 935-938. 
6. Matsuki T, Kaga A, Kanda S, Suzuki Y, Tanabu M, Sawa N. Intestinal malrotation with suspected cow's milk allergy. BMC Research Notes 2012; 5: 481.

7. Vlieghe V, Des Roches A, Payot A, Lachance C, Nuyt AM. Human milk fortifier in preterm babies: source of cow's milk protein sensitization? Allergy 2009; 64: 1690-1691.

8. Alabsi HS, Reschak GL, Fustino NJ, Beltroy PE, Sramek JE, Alabsi YS. Neonatal eosinophilic gastroenteritis: Possible in utero sensitization to cow's milk protein. Neonatal Netw 2013; 32: 316-322.

9. Yada K, Yoshida K, Sakurai Y, et al. Casein hydrolysate formula-induced liver dysfunction in a neonate with non-immunoglobulin E-mediated cow's milk allergy. J Investig Allergol Clin Immunol 2008; 18: 67-70.

10. Ward CM, Geng L, Jyonouchi H. Fetal sensitization to cow's milk protein and wheat: cow's milk protein and wheat-specific TNF-a production by umbilical cord blood cells and subsequent decline of TNF-a production by peripheral blood mononuclear cells following dietary intervention. Pediatr Allergy Immunol 2007; 18: 276280.

11. Faber MR, Rieu P, Semmekrot BA, Van Krieken JH, Tolboom JJ, Draaisma JM. Allergic colitis presenting within the first hours of premature life. Acta Paediatr 2005; 94: 1514-1515.

12. Corrado G, Cavaliere M, D'Eufemia P. Sandifer's syndrome in a breast-fed infant. Am J Perinatol 2000; 17: $147-150$.
13. Kumar D, Repucci A, Wyatt-Ashmead J, Chelimsky G. Allergic colitis presenting in the first day of life: report of three cases. J Pediatr Gastroenterol Nutr 2000; 31: 195-197.

14. Wilson NW, Self TW, Hamburger RN. Severe cow's milk induced colitis in an exclusively breast-fed neonate. Case report and clinical review of cow's milk allergy. Clin Pediatr (Phila). 1990; 29: 77-80.

15. WHO Division of Child Health and Development Indicators for Assessing Breastfeeding Practices. Report of an Informal Meeting in June 1991, Geneva (accessed October 25,2011).

16. D'Netto MA, Herson VC, Hussain N, et al. Allergic gastroenteropathy in preterm infants. J Pediatr 2000; 137: 480-486.

17. Academy of Breastfeeding Medicine. ABM Clinical Protocol \#24: Allergic Proctocolitis in the Exclusively Breastfed Infant. Breastfeed Med 2011; 6: 435-440.

18. Brill H. Approach to milk protein allergy in infants. Can Fam Physician 2008; 54: 1258-1264.

19. Thompson-Chagoyan OC, Vieites JM, Maldonado J, Edwards C, Gil A. Changes in faecal microbiota of infants with cow's milk protein allergy-a Spanish prospective case-control 6-month follow-up study. Pediatr Allergy Immunol 2010; 21: 394-400.

20. Donati L, Di Vico A, Nucci M, et al. Vaginal microbial flora and outcome of pregnancy. Arch Gynecol Obstet 2010; 281: 589-600. 